\title{
'Biomarking' infection during continuous renal replacement therapy: still relevant?
}

\author{
Patrick M Honore*, Rita Jacobs, Inne Hendrickx, Elisabeth De Waele, Viola Van Gorp and Herbert D Spapen \\ See related research by Park et al., http://ccforum.com/content/18/6/640
}

We greatly appreciated the recent research article by Park and colleagues in Critical Care showing that procalcitonin (PCT) is not superior to C-reactive protein (CRP) as a marker for infection in renal impairment [1]. Additionally, we would like to comment on the validity of CRP and PCT measurement during continuous renal replacement therapy (CRRT). Both acute-phase proteins are indeed effectively cleared by CRRT. CRP is predominantly present as a monomer (mCRP) in the blood [2] and is removed by all forms of CRRT because its molecular weight $(22-25 \mathrm{kDa})$ lies below the cutoff permeability limits of all classic dialysis membranes [3]. Most of the PCT mass is easily eliminated by convection [4]. However, although $\mathrm{mCRP}$ and PCT are adequately filtered, substantial amounts of both are adsorbed on the dialysis membrane $[3,4]$. Therein lies a clinically relevant but poorly recognized problem! In fact, highly adsorptive dialysis membranes are increasingly applied to CRRT in many intensive care units worldwide. The use of such membranes will inherently accentuate mCRP and PCT removal. As a result, plasma levels of both biomarkers risk becoming falsely low during CRRT and thereby losing all potential to help clinicians diagnose or evaluate infection. The recently introduced sepsis biomarkers brain natriuretic peptide and $\mathrm{N}$-terminal pro-brain natriuretic peptide have been proclaimed to be superior to CRP and PCT, but whether they perform better under CRRT is doubtful because their molecular weights ( 3.5 and $8.5 \mathrm{kDa}$, respectively) already predict highly effective clearance by both high- and lowflux membranes [5].

\section{Abbreviations}

CRP: C-reactive protein; CRRT: Continuous renal replacement therapy; mCRP: Monomeric C-reactive protein; PCT: Procalcitonin.

\section{Competing interests}

The authors declare that they have no competing interests.

Published online: 21 May 2015

\section{References}

1. Park JH, Kim DH, Jong HR, Kim MJ, Jung SH, Lee JH, et al. Clinical relevance of procalcitonin and C-reactive protein as infection markers in renal impairment: a cross-sectional study. Crit Care. 2014;18:640.

2. Taylor KE, van den Berg CW. Structural and functional comparison of native pentameric, denatured monomeric and biotinylated C-reactive protein. Immunology. 2007;120:404-11.

3. Honore PM, Jacobs R, De Waele E, Van Gorp V, Spapen HD. Biomarkers of inflammation during continuous renal replacement therapy: sensors, players, or targets ? Blood Purif. 2014;38:102-3.

4. Dahaba AA, Elawady GA, Rehak PH, List WF. Procalcitonin and proinflammatory cytokine clearance during continuous venovenous haemofiltration in septic patients. Anaesth Intensive Care. 2002;30:269-74.

5. Wahl HG, Graf S, Renz H, Fassbinder W. Elimination of the cardiac natriuretic peptides B-type natriuretic peptide (BNP) and N-terminal proBNP by hemodialysis. Clin Chem. 2004;50:1071-4.

\footnotetext{
* Correspondence: patrick.honore@az.vub.ac.be
ICU Department, Universitair Ziekenhuis Brussel, Vrije Universiteit Brussel

* Correspondence: patrick.honore@az.vub.ac.be
ICU Department, Universitair Ziekenhuis Brussel, Vrije Universiteit Brussel

University, 101, Laarbeeklaan, 1090 Jette, Brussels, Belgium
}

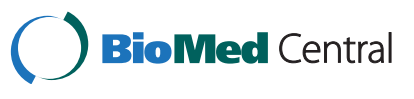

(c) 2015 Honore et al.; licensee BioMed Central. This is an Open Access article distributed under the terms of the Creative Commons Attribution License (http://creativecommons.org/licenses/by/4.0), which permits unrestricted use, distribution, and reproduction in any medium, provided the original work is properly credited. The Creative Commons Public Domain Dedication waiver (http://creativecommons.org/publicdomain/zero/1.0/) applies to the data made available in this article, unless otherwise stated. 